\title{
Costs of 2001 methyl bromide rules estimated for California strawberry industry
}

\author{
Colin A. Carter \\ James A. Chalfant \\ Rachael E. Goodhue \\ Gregory J. McKee \\ $\nabla$
}

The California Department of Pesticide Regulation (DPR) restricts pesticide use to reduce negative impacts on human health and the environment. The DPR implemented methyl bromide use regulations in 2001. Our study demonstrates that the estimated 2001 costs of these regulations for the California strawberry industry were quite substantial (more than \$26 million total), equivalent to roughly $25 \%$ of estimated industry returns over total cash costs in 2001. These impacts were unevenly distributed across growers. Growers with small fields in urban areas had higher peracre costs than growers with large fields in agricultural areas.

$\mathrm{T}$ he California Department of Pesticide Regulation's (DPR) mandate is to protect human health and the environment from the negative effects of pesticide use (Federighi 2001). In order to achieve this goal, the DPR uses a number of regulatory tools, including pesticide use restrictions. Use restrictions are rules that are not included on the pesticide's label, such as buffer zones or application limits based on the treatment date or location. Some use restrictions are intended to protect the applicator's health, such as protective equipment requirements or limits on the hours of exposure. Other use restrictions are intended to protect other people from exposure. Local environmental impacts may be reduced by measures such as prohibiting applications when the ambient air temperature is above a specified threshold.

The DPR's use regulations are administered through a permit process. In order to apply a restricted-use pesticide,

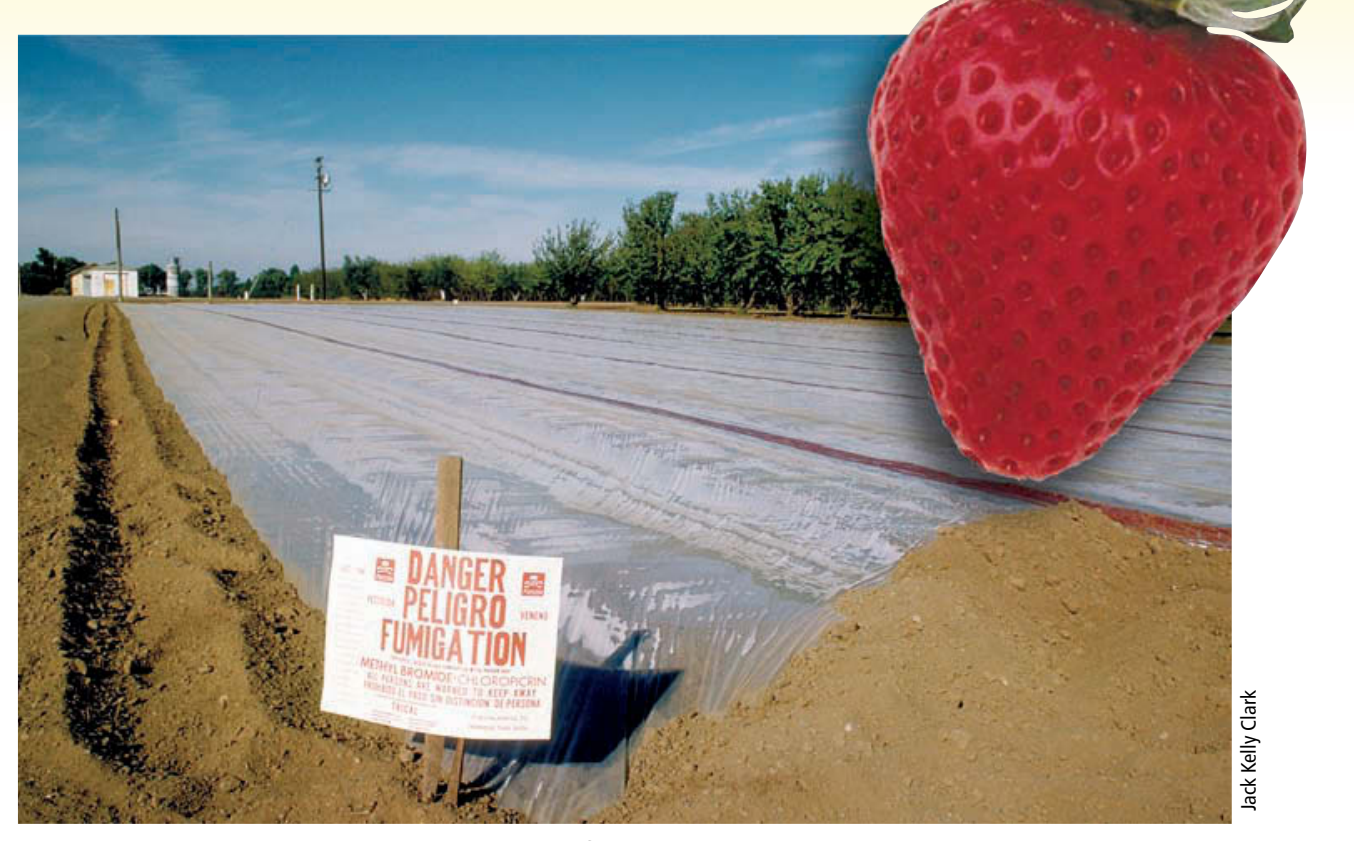

Methyl bromide has been widely used in California - especially in strawberry production - to fumigate soil prior to planting and prevent nematodes and other soil-borne pests. The California Department of Pesticide Regulation requires growers to warn the public of possible exposure to the toxic fumigant.

the grower must obtain a permit from the county agricultural commissioner. Based on scientific assessments of the potential effects of a pesticide on human health and the environment, the DPR provides the commissioners with "suggested permit conditions," which reflect DPR's judgment regarding "minimum measures necessary to protect people and the environment" (Federighi 2001). At their discretion, commissioners may alter these conditions to reflect local circumstances.

We examined the cost impact of use regulations imposed in 2001 on methyl bromide, a widely used preplanting soil fumigant, on the California strawberry industry. Human exposure to high concentrations of methyl bromide can be irritating to the eyes, airways and skin, while acute and chronic exposure can lead to a degeneration of nerve cells. The regulations were aimed at reducing human exposure to methyl bromide by limiting emissions and restricting human activity near fumigation sites.

Furthermore, under the United $\mathrm{Na}-$ tion's Montreal Protocol on Substances That Deplete the Ozone Layer, methyl bromide is scheduled to be banned in the United States and other developed nations in the 2005 calendar year (but an exemption process allows critical uses to receive temporary waivers). The ban has been gradually phased in; the permissible quantity of methyl bromide sold nationally is declining, and the rate of decline is linked to a percentage of 1991 consumption. As of 2001 when we conducted our study, the main effect of the phase-out requirements on California strawberry growers was a higher price for methyl bromide, whereas in some other crops use had declined substantially. Overall, methyl bromide usage in California strawberry production had not declined dramatically, and remained at about 3.8 million pounds in 2001 (table 1). Since 2001 the use of methyl bromide in strawberry fields has not substantially declined.

Strawberry growers fumigate the soil prior to planting in order to control weeds, nematodes and other soil-borne pests. While there are chemical alternatives to methyl bromide for strawberry production, their future availability is also in question due to human health and environmental concerns. At the present time, one alternative fumigant, 


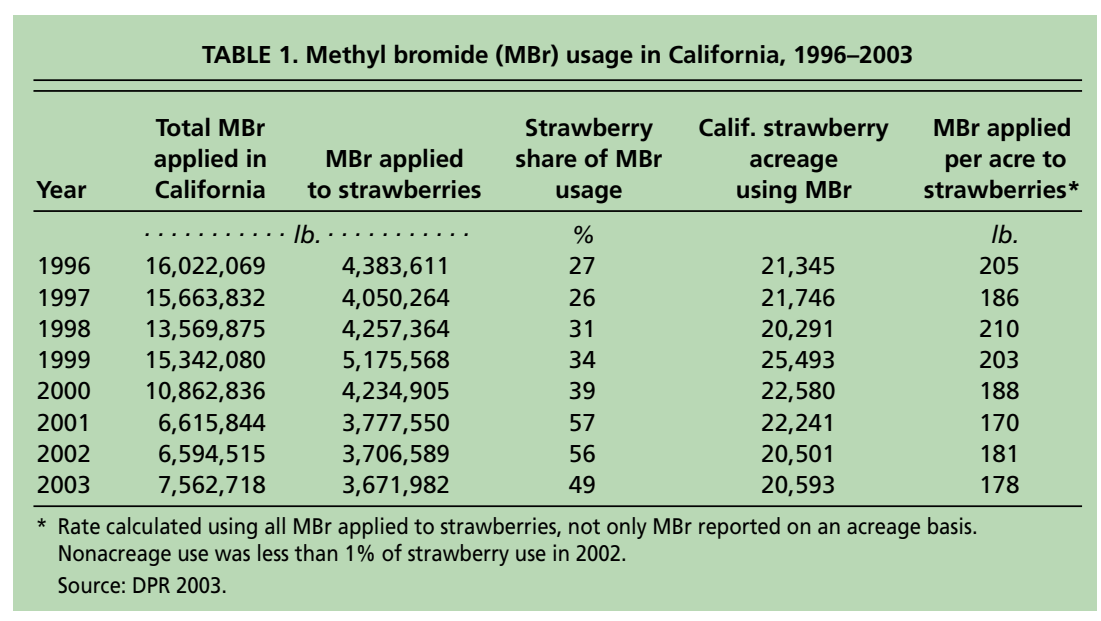

\section{1,3-D, is on California's Proposition 65} list of chemicals known to increase the risk of cancer, and is subject to township caps; these limits are intended to regulate lifetime exposure to 1,3-D. Another chemical alternative, chloropicrin, is currently being evaluated by the DPR under its risk assessment process. In 2001, all chloropicrin products were put into reevaluation by the DPR due to potential negative health effects at low doses (DPR 2004).

The overall economic impacts of the global methyl bromide ban are also unclear. Analyses of the economic viability of methyl bromide alternatives using field trial results have had mixed results (Goodhue et al. in press). According to DPR's pesticide use report, in 2002 roughly $25 \%$ of California's strawberry acreage was fumigated using methyl bromide alternatives, which suggests that some growers find them economically superior to methyl bromide (DPR 2003). It is difficult to evaluate the contribution of the DPR use regulations to this shift.

Our analysis focused on the impact of the 2001 methyl bromide use regulations on industry costs. We did not incorporate any changes in industry revenues that may offset these costs, nor did we measure the total social costs and benefits of the regulations. Estimating the human health and other benefits of the 2001 methyl bromide use regulations was beyond the scope of our analysis. Similarly, we did not attempt to measure the costs of the use regulations to anyone besides growers.

\section{California strawberry industry}

California's total fresh and processed strawberry sales were $\$ 805.8$ million in 2001. In a typical year, strawberries rank as one of the top 10 most valuable crops in the state (CDFA 2002). In 2001, the leading counties in terms of value of strawberry production were Monterey (32.8\%), Ventura (27.4\%), Santa Cruz (17.8\%), Santa Barbara (9.0\%) and Orange $(6.2 \%)$, together representing over $90 \%$ of the total value of production. Every year, growers expend almost $\$ 30,000$ per acre to produce and harvest strawberries, so even a 30-acre farm has an outlay of about $\$ 1$ million per year. Based on the UC cost and return budgets for strawberries, statewide net grower returns above total cash costs are roughly $\$ 103.7$ million (Klonsky and De Moura 2001).

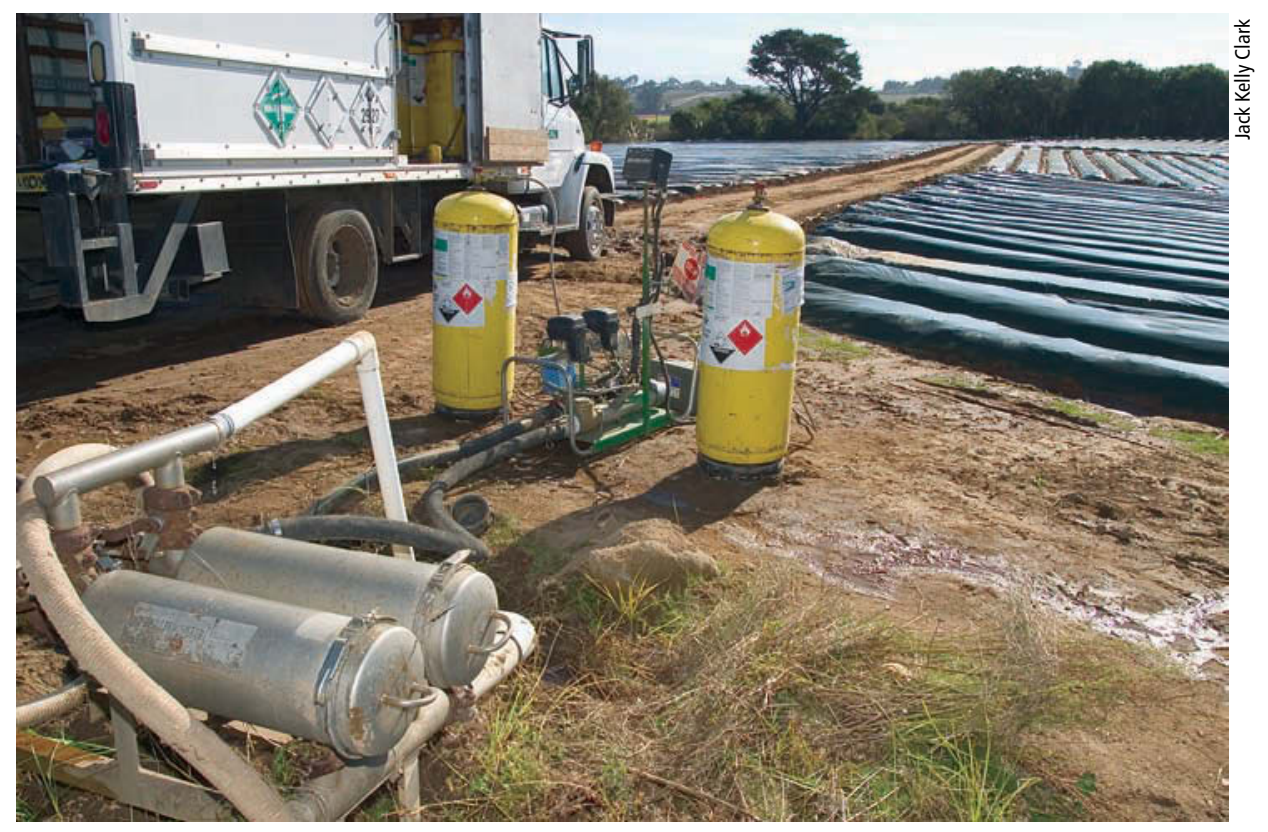

Due to its impact on the ozone layer, methyl bromide is being gradually phased out. Above, one alternative fumigant is a mixture of 1,3-dichloropropene and chloropicrin, which is injected into the irrigation system. However, these chemicals are also subject to strict regulatory controls. 


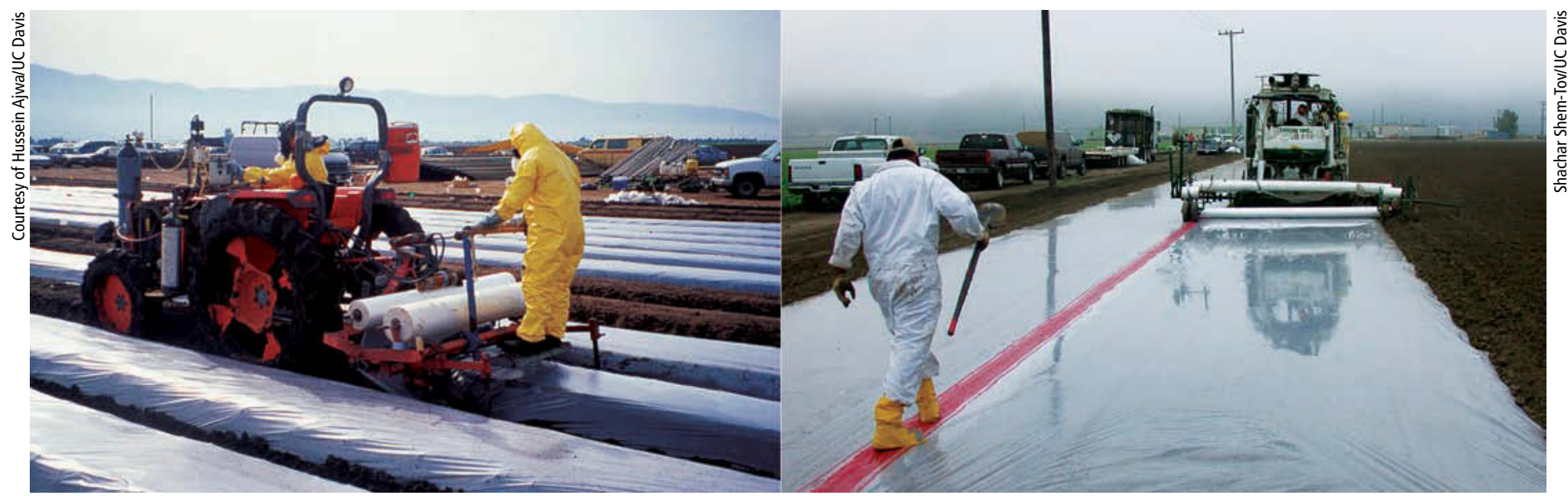

In 2001, state regulators imposed new regulations on methyl bromide applications, which included buffer zones to limit exposure. The authors found that many strawberry growers were forced to switch from bed fumigation, left, where the beds are formed and then treated, to more expensive flat fumigation, right, in which the process is reversed.

The inner buffer zone extended a minimum of 50 feet from the edge of the application block, and increased with the size of the acreage block and the application rate. Only individuals involved in the fumigation process were allowed into the inner buffer zone. These individuals were subject to additional use restrictions, which specified the maximum exposure times for various fumigation tasks. The inner buffer zone had to be on agricultural land or a public roadway and could not extend onto any adjacent nonagricultural land.

The outer buffer zone extended at least 60 feet from the edge of the block and increased with the size of the acreage block and the application rate. People were allowed into the outer buffer zone for transit purposes or to "conduct activities approved by the county agricultural commissioner." Here, individual exposure was limited to no more than 12 hours out of any 24 . The outer buffer zone was not limited to agricultural land. Even if the buffer-zone requirements were not binding, the 2001 DPR regulations limited total acreage for a single fumigation block to a maximum of 40 acres in any 24-hour period.

A neighborhood notification requirement was also included in the use restrictions. It specified that property owners within 300 feet of the outer buffer zone had to be notified that an application permit had been approved at least 9 days prior to the initiation of fumigation. Those receiving the initial notification could choose to request specific notification of the exact date and time at least 48 hours prior to the initiation of fumigation.

\section{Impacts of regulations}

To evaluate the costs of the 2001 DPR methyl bromide fumigation regulations for the California strawberry industry, we collected copies of available, completed fumigation permits and worksite plans for strawberry fields in the five counties producing the most strawberries: Monterey, Orange, Santa Barbara, Santa Cruz and Ventura. In total we collected more than 400 worksite plans and permits for 2001 from the county agricultural commissioners' offices. Simulation analysis was conducted using work-plan data to determine the effects of the buffer zones. This involved the development of a mathematical model of the fumigation regulations; we then asked the model to solve for optimal fumigation practices, given the many different field configurations found in the work-plan data. Our analysis also utilized information from about 20 growers identified by the county agricultural commissioners' offices and encountered at field days and other venues.

Buffer zones. A notable impact of the DPR regulations on growers was that some acreage could no longer be fumigated with methyl bromide due to the buffer-zone requirements. This impact varied by location, field size and field shape. As a result, growers had to replace the strawberries that would have been grown on this acreage with a less valuable crop, or they suffered yield losses on their unfumigated strawberry acreage.

Fields with more nonagricultural borders lost a larger percentage of their total acreage, holding other factors constant. For example, a square 10-acre field with one 50-foot buffer extending into the field itself would not be able to fumigate $7.6 \%$ of its total acreage. If it had two adjoining buffered sides, the nonfumigated acreage would increase to $14 \%$ of the total; $21.6 \%$ and $28 \%$ of the total acreage would be nonfumigated for three and four buffered sides, respectively. Fields near urban areas were more likely to be unable to fumigate a greater share of acreage than those in agricultural areas.

For a given buffer-zone restriction, smaller fields lost a larger percentage of their total acreage. For example, a square 20-acre field with one buffered side had 1.07 nonfumigated acres, or $5.4 \%$ of the total. In contrast, a square 10 -acre field had 0.76 nonfumigated acre, or $7.6 \%$ of the total. This difference increased with the number of buffered sides. If all four sides were bordered by nonagricultural uses, the 20-acre field's nonfumigated acreage would be $20.3 \%$ of the total, while the 10 -acre field's nonfumigated acreage would be $28 \%$.

The difference in percentage of acreage lost increased with the difference in field size. For a square 50-acre field, $3.4 \%$ of its acreage would be nonfumigated when it had one buffered side, and $13.1 \%$ would be nonfumigated when it had four buffered sides. Average field size by county varies: in the work plans we collected, it ranged from 28.1 acres in Santa Cruz County to 60.4 acres in Ventura County. In Santa Cruz County, $54 \%$ of the fields were less than 25 acres, compared with only $24 \%$ in 


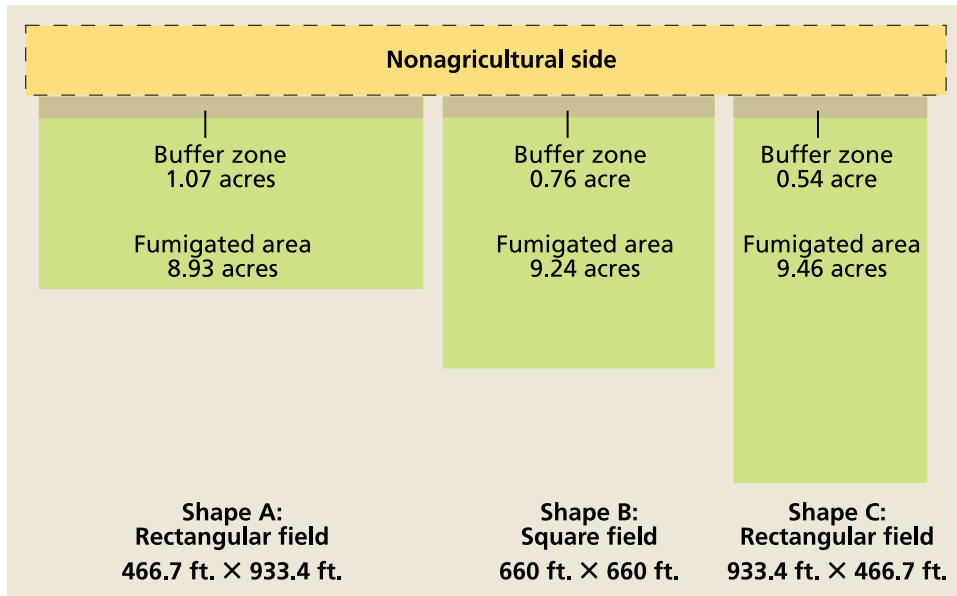

Fig. 1. Hypothetical acreage loss for a 10-acre field due to 50-foot buffer.

Ventura County. Ignoring any systematic variations in field shape and the number of buffered sides, the differences in field size suggest that the impact of the buffer-zone regulations varied across counties.

For a given field size and buffer-zone restriction, field shape also affected the share of nonfumigated acreage (fig. 1). The three fields in the figure are each 10 acres. Each field has one side where the adjacent property is in a nonagricultural use, so that the inner buffer zone reduces the fumigated acreage. For the square field (shape B), the inner buffer-zone requirement reduces the fumigated acreage by $7.6 \%$. In contrast, for the rectangular field with a long side bordering the nonagricultural use (shape A), the inner buffer-zone requirement reduces the fumigated acreage by $10.7 \%$. On the other hand, a rectangular field with a short side bordering a nonagricultural use (shape C) loses only $5.4 \%$ of its fumigated acreage. (In figure 1 , the long side is twice as long as the short side.)

Our analysis helped to clarify what share in the effects of the regulations across counties was due to differences in field shape, and what share was due to differences in the proximity to residential areas and sensitive sites. We observed that growers in areas with higher population densities were much more likely to be heavily affected by the buffer zone, permission and notification requirements. Growers with smaller fields faced a proportionately greater loss of fumigated acreage than growers with large fields. We used data collected from actual permit applications to determine the acreage for individual fields that could not be fumigated due to inner buffer-zone requirements. Using per-acre net revenue estimates from 2001 cost and return studies by Klonsky and De Moura (2001), we found that there was an industry loss of $\$ 3.2$ million due to the inability to fumigate acreage comprising inner buffer zones.

Processing-strawberry sales. On average, during the 4 years immediately prior to the enactment of the 2001 DPR regulations, approximately 417 million pounds of California strawberries were sold annually to processors, about $30 \%$ of annual production. The 2001 DPR regulations significantly lengthened the fumigation period, disrupting the normal pattern of sales to the processing market. The longer fumigation period reduced sales to the freezer market, because growers had to remove the plants from the previous season earlier than in prior years, which reduced production. Some growers in Southern California lost up to 4 weeks of processing-market sales. Assuming 2,500 pounds per acre per week of processing berries at the 2001 average price of $30.6 \$$ per pound (CPSAB 2001), the estimated revenue loss was $\$ 765$ per acre per week. After harvest costs of about $14 \$$ per pound, the gross profit on these sales would be approximately $\$ 415$ per acre per week or $16.6 \$$ per pound.

Many growers reported that they lost production at the end of the season due to the 2001 DPR fumigation regulations. Data from the California Process- ing Strawberry Advisory Board shows a decline in the 2001 freezer volume to 338.9 million pounds (or $25.7 \%$ of annual state production). This is below the previous 5-year average of 421.7 million pounds (30.5\% of production). We estimate that about three-fourths of the total decline of 82.8 million pounds was due to the DPR regulations. This volume decline of almost 63 million pounds represents an estimated loss of approximately 1 week's production, on average, for every acre in the state. The revenue loss associated with this volume loss was approximately $\$ 10.4$ million for California growers. This is likely to be a conservative estimate, as some growers lost much more than 1 week.

Additional fumigation days. The 2001 DPR regulations lengthened the time period necessary for methyl bromide fumigation for all growers in the state. As indicated, the extent to which the fumigation period was extended varied by factors such as field shape, location, pounds of methyl bromide applied and fumigation method.

Total fumigation costs per acre increased due to the diseconomies of fumigating relatively small pieces of land each day, with additional costs such as labor and equipment rentals. The diseconomies were more costly per acre for smaller fields. For instance, in Santa Barbara County it took one grower 9 days to fumigate a 9-acre field in 2001. In the same county, it took another grower the same number of days to fumigate a 40-acre field. Based on grower information and budget data, we estimate that nonchemical fumigation costs increased by at least $40 \%$ due to the longer fumigation period. This translates into a cost increase of about $\$ 400$ per acre, resulting in an estimated industry loss of about $\$ 10$ million. In all likelihood, this is a conservative estimate of the higher costs.

Bed vs. flat fumigation. Due to regulatory specifications for emissions ratios, the buffer-zone requirements were much more onerous for "bed" fumigation, where only the raised beds are fumigated, than for "flat" fumigation, where the entire field is fumigated 


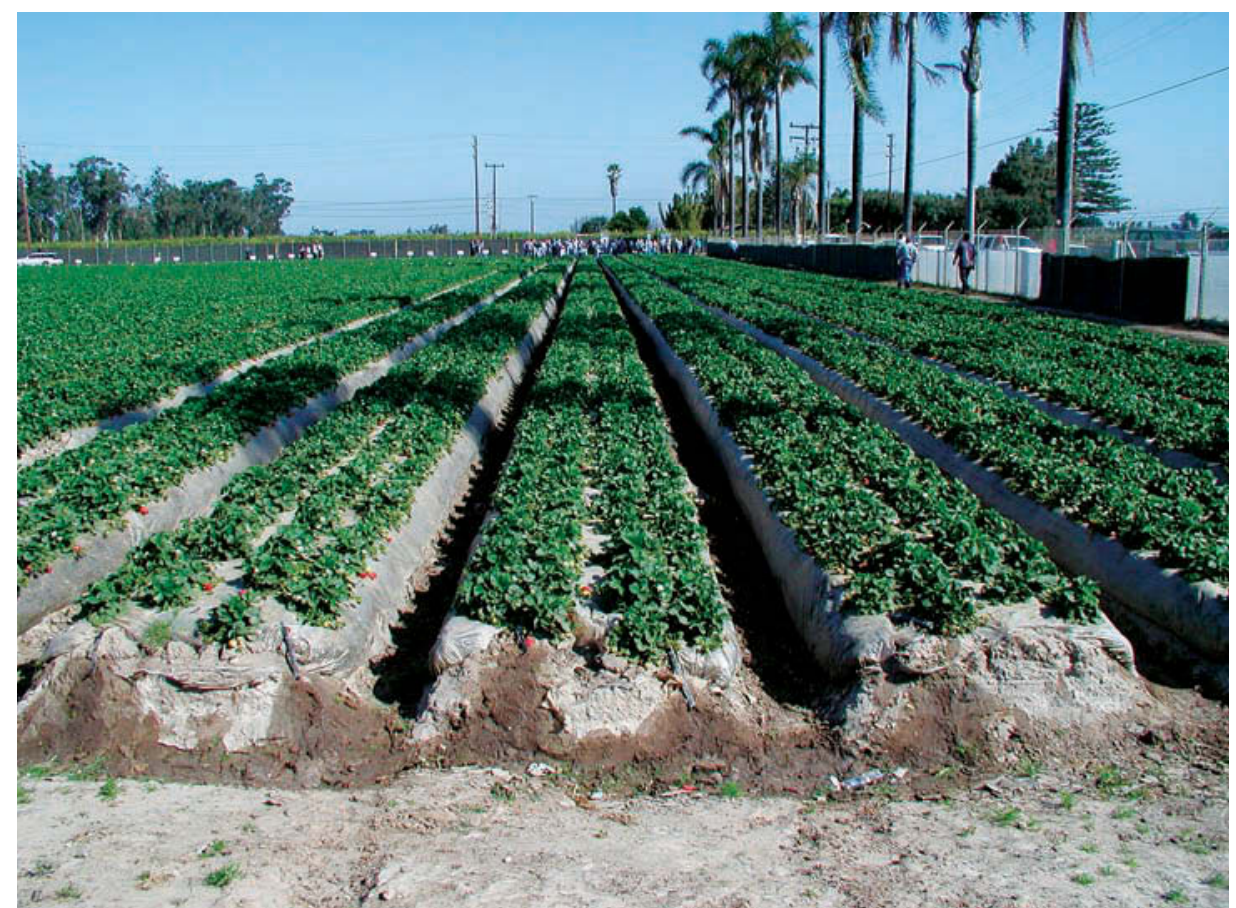

After the methyl bromide rules were implemented, growers reported increased costs and lost income due to lower yields on untreated acreage, reduced sales to the freezer market, and additional labor, equipment and notification costs.

prior to bed construction. The scientific studies consulted by the DPR indicated that bed fumigation had a much larger emissions ratio than flat fumigation, so that human exposure to methyl bromide was much greater given the amount of methyl bromide applied. In order to provide the same protection for human health, larger buffer zones were required for bed fumigation. Due to the larger buffer zones and the associated loss of fumigated acreage, some growers found it preferable to switch to flat fumigation. Flat fumigation is much more expensive, however, at least an estimated $\$ 1,000$ per acre more than bed fumigation. This regulation benefited pesticide applicators, because most growers did not have the equipment necessary for flat fumigation and had to hire custom applicators.

Growers in Santa Barbara County were most affected by the 2001 DPR regulation. There are more than 3,000 acres of strawberries grown in Santa Barbara County, and this acreage was virtually all bed-fumigated prior to the growing season. In order to maintain economic viability, county producers switched between $20 \%$ and $25 \%$ of these acres from bed to flat fumigation in 2001, requiring a move to commercial applicators and increasing application costs for county producers by about $\$ 700,000$. The switching costs in Ventura County were estimated at about $\$ 500,000$ (500 acres); Monterey County, $\$ 700,000$ (700 acres); Santa Cruz County, $\$ 300,000$ (300 acres); and Orange County, $\$ 200,000$ (200 acres). Total switching costs are therefore estimated to be approximately $\$ 2.4$ million for 2001 .

Notification costs. Overall, our analysis of the work-plan data indicated that notifications, and notification costs per acre, varied substantially across fields. Smaller fields tended to have higher notification costs per acre. Fields near urban areas or rural residential developments had a larger number of notifications and higher notification costs per acre, on average. The estimated notification costs ranged from $\$ 1.67$ per acre in Santa Barbara County to $\$ 9.66$ per acre in Orange County. However, the Orange County estimates were based on a relatively small sample, so those estimates may not accurately reflect average costs per acre for all fields, and the Santa Barbara estimates excluded prefumigation 48-hour notices, underestimating per-acre costs.

Based on information from growers, the average notification required 30 minutes to prepare the paperwork plus travel time to notify the neighbor
TABLE 2. Estimated statewide costs of 2001 DPR methyl bromide use restrictions to California strawberry growers

\begin{tabular}{lc}
\hline \hline Cost & \$ (millions) \\
\hline Applying buffer zones & 3.2 \\
Lost processing-strawberry sales & 10.4 \\
Additional fumigation time & 10.0 \\
Switch from bed to flat fumigation & 2.4 \\
Notification & 0.125 \\
\hline Total & 26.125
\end{tabular}

(sometimes including multiple trips to find the neighbor at home). We valued the management/supervisor labor used for conducting notifications at $\$ 20$ per hour, or roughly twice the cost of field labor. Together, these values indicate that the average per-acre notification costs were approximately $\$ 10$, excluding mileage, copying and other costs. The overall notification cost was estimated by weighting the individual county estimates by production. This generated an average cost of about $\$ 5$ per acre, or $\$ 125,000$ for the state.

\section{Where do the regulations stand now?}

Impacts on growers are just one part of the regulatory environment for agricultural chemicals. A complex set of political and legal processes came into play with the 2001 methyl bromide use regulations, and cost-benefit analyses that can be done using economic impacts are just one part of the picture. In February 2002, San Francisco Superior Court Judge A. James Robertson set aside the regulations. He ruled that the DPR improperly set up the regulations and should have consulted with the California Department of Food and Agriculture before implementing them.

The court ruling also imposed a new requirement that state agencies must consider the economic impact of the proposed regulations, although it is not entirely clear that such consideration will have any effect on regulations. In response, in 2002 the DPR introduced emergency regulations for methyl bromide application. A slightly revised version of the 2001 regulations was permanently introduced in November 2004 (see page 5). For the purposes of our analysis, the only notable difference between the 2004 permanent regulations and the 2001 temporary regulations is that the minimum, inner buffer-zone 


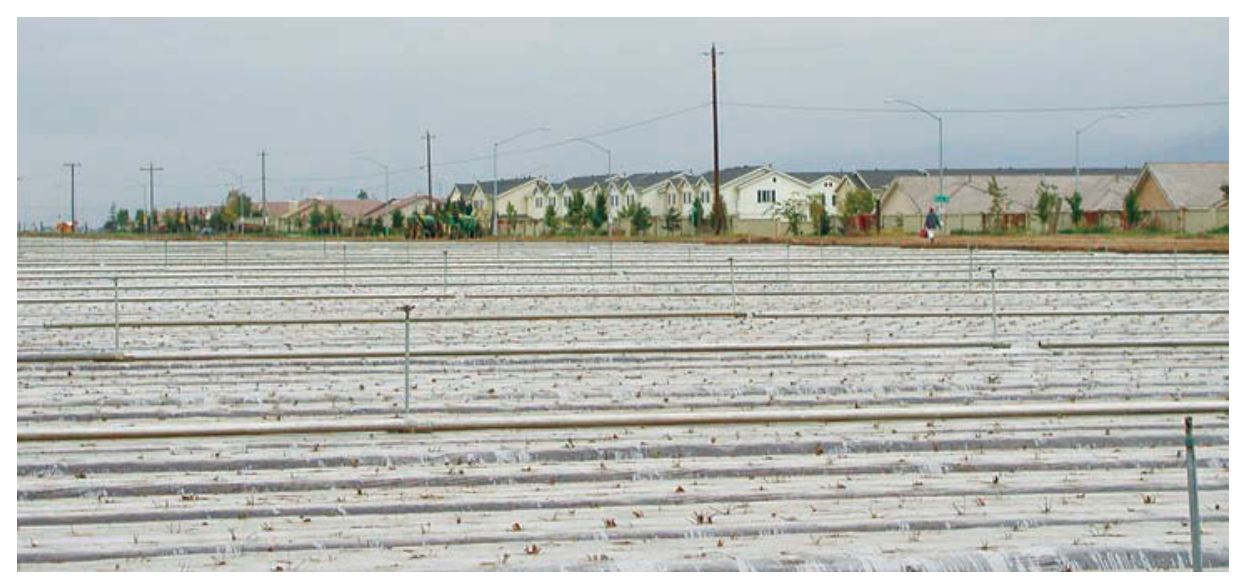

Near Salinas, strawberry fields are directly adjacent to residential areas. If growers choose not to farm at the rural-urban interface due to regulatory concerns, such agricultural lands could be at greater risk of conversion to residential or commercial uses.

was reduced from 50 to 30 feet for very low emissions per acre and relatively small application blocks.

\section{Costs of regulation considered}

State-level pesticide use regulations are intended to protect human health and the environment. Our analysis does not imply that such regulations are not socially desirable, or that they are excessively costly when compared to their benefits. Rather, it estimates the costs of a specific set of regulations and illustrates how the cost burden of such regulations was distributed across growers. In many cases, such information can be used to suggest alternative sets of regulations that achieve the same health outcomes at a lower cost to growers.

We conclude that the short-term impact of the 2001 DPR use regulations for methyl bromide to growers in the strawberry industry was significant, with the total estimated costs exceeding $\$ 26$ million (table 2). The two most significant components were the reduction in the volumes marketed for processing, due to the increased time needed to fumigate for the following season, and increased fumigation costs. To the extent that growers found it difficult to implement a plan consistent with the DPR regulations, or difficult to arrange a fumigation schedule, we have understated impacts on those growers. To the extent that industry revenues increased due to reduced production, especially for processed strawberries, our estimate of increased costs overstates the effect of the regulations on industry profits.

We found that the costs were unequally distributed across growers. Growers in urbanized areas, especially with small fields, were affected the most on a per-acre basis. Differences in the estimated emissions of different application methods led to large per-acre differences in the cost of the regulations for different growers. Some growers were forced to change their fumigation method and hire commercial applicators. In addition, grower costs increased because, in many cases, it took three to four times longer to fumigate each field. The extended fumigation period also reduced revenue from the processing market for the old crop.

Apart from the direct evaluation of the industry costs of the 2001 methyl bromide use regulations, our analysis illustrates three general issues associated with use regulations. First, regulations that alter the timing of pesticide application, by limiting acres or hours of applicator exposure per unit of time, may have costly indirect effects. In the case of strawberries, the harvest season was truncated by the lengthened application period, which reduced industry revenues. Second, regulations that vary by application methods may have different effects on the costs of different application methods. In the case of strawberries, the buffer-zone specifications resulted in so much lost acreage under bed fumigation that many growers were forced to move to more-expensive flat fumigation and hire commercial applicators. Third, buffer-zone regulations designed to limit human, nonapplicator exposure will have unequal effects across growers.

The types of costs borne by growers provide an indication of those that may accompany new restrictions on other chemicals. Our findings illustrate that new pesticide regulations may contribute to the increasing cost and difficulty of farming at the urban-rural interface, especially when agricultural areas are fragmented. If so, this type of regulation will encourage growers to stop farming at the interface, which may increase the rate of agricultural land conversion for residential and commercial construction. Accordingly, such regulations may influence the spatial distribution of California agriculture and may reduce the amount of open space remaining near California's urban areas.

\section{C.A. Carter is Professor, J.A. Chalfant is}

Professor and Chair, R.E. Goodhue is Associate Professor, and G.J. McKee is Graduate Student, Department of Agricultural and Resource Economics, UC Davis. Carter, Chalfant and Goodhue are members of the Giannini Foundation of Agricultural Economics. The California Department of Food and Agriculture (CDFA) funded this research. The opinions in this article are the authors', not those of the CDFA.

\section{References}

[CDFA] California Department of Food and Agriculture. 2002. California Department of Food and Agriculture Resource Directory. Sacramento, CA. 180 p.

[CPSAB] California Processing Strawberry Advisory Board. 2001. 2001 Annual Report. Watsonville, CA. $18 \mathrm{p}$.

[DPR] California Department of Pesticide Regulation. California Pesticide Information Portal. 2003. http://calpip.cdpr.ca.gov/cfdocs/ calpip/prod/main.cfm

DPR. 2004. Status Report for Fumigant Pesticides. Sacramento, CA. 6 p. www.cdpr. ca.gov/docs/dprdocs/methbrom/stat0704.pdf

Federighi V. 2001. Regulating Pesticides: The California Story. California Department of Pesticide Regulation, California Environmental Protection Agency. Sacramento, CA.

Goodhue RE, Fennimore SA, Ajwa HA. In press. The economic importance of methyl bromide: Does the California strawberry industry qualify for a critical use exemption from the methyl bromide ban? Rev Agric Econ.

Klonsky K, De Moura RL. 2001. Fresh Market Strawberries, Central Coast (Rep \#ST-CC-01); Fresh Market, Freezer Strawberries, South Coast, Santa Maria Valley (Rep \#ST-SC-01-1); Fresh Market, Freezer Strawberries, South Coast, Ventura County (Rep \#ST-SC-01-2). UC Cooperative Extension, and Department of Agricultural and Resource Economics, UC Davis. www.agecon.ucdavis. edu/outreach/crop/archived-crop/strawberries.htm 